\title{
Material Investments as a Factor of Restructuring Small Agricultural Holdings with Non-agricultural Activities
}

\author{
Katarzyna ŻMIJA \\ Cracow University of Economics, Cracow, Poland \\ zmijak@uek.krakow.pl
}

\begin{abstract}
The aim of the study is to analyse material investments carried out between 2004 and 2015 by small agricultural holdings owners conducting at the same time non-agricultural activities and their plans regarding the future of their activities. The empirical material consisted of results of own survey-based research conducted in 2015 among farmers from Małopolskie Province owning agricultural holdings of $1-5$ ha of arable land and conducting non-agricultural activities at the same time. Analysing the directions of devoting resources to investments, it was found that these persons usually invested both in agricultural and non-agricultural activities; some regularities of directions of devoting resources depending on the type of non-agricultural activity can be observed though. In general, more resources were devoted to non-agricultural activity. The research showed that both the nature of investment decisions of the farmers and their declarations demonstrate willingness to conduct agricultural and non-agricultural activities simultaneously.
\end{abstract}

Keywords: Small Farms, Non-agricultural Activities, Investments.

\section{Introduction}

Since the beginning of the 1990s, intense transformation processes polarising the spatial, production, and economic structure of agricultural holdings have been observed. These changes are a result of the changing position of agriculture in the economy and broad socio-economic changes taking place in Poland, including its rural areas $[5,8]$. So far, science and economic practice have focused mainly on bigger holdings conducting marketable production and having potentially better developmental abilities. Less attention was paid to smaller and economically weaker holdings and the necessity of reducing their number was considered the main direction of restructuring of the agricultural sector in Poland [2, 6, 9].

Statistical data shows a systematic decrease in the number of small agricultural holdings in Poland. According to Eurostat, in 2013 there were 770 thousand holdings with less than 5 ha of arable land, whereas in 2010 there were over 823 thousand [1]. It is worth noting that they show high permanence and form dominant structures in many regions of Poland. Their permanence is a result of many noneconomic factors determining the behavior of the owners of these entities on one hand and of the fact that the owners usually also have non-agricultural or unearned sources of incomes, 
which make small holdings, contrary to the big ones, resistant to different economic incentives and less vulnerable to increasingly frequent fluctuations on agricultural markets. Additionally, they are dependent on political changes and unstable agricultural policy to a lesser extent $[4,7,10]$. Therefore, they will surely prevail in many Polish regions for a long time to come.

Due to the economic weakness of many small agricultural holdings, some of their owners still look for opportunities to increase their incomes, choosing diverse strategies. Some decide to specialise or intensify agricultural production and focus on the segments allowing for a reasonable rate of return. These actions are usually accompanied by land extension, holding modernisation, starting cooperation with other entities on the market, which creates opportunities for the gradual accession of these holdings into the group of developmental and commercial holdings closely related with the market. The second group consists of agricultural holdings owners looking for alternative sources of income, such as employment or non-agricultural business activity of the farmer or their family. Diversifying income sources may lead to numerous benefits, but also to reduction of agricultural activity or, in extreme cases, to slow withdrawal from it leading to total liquidation of an agricultural holding $[3,9]$.

This study focuses on small agricultural holdings owners following the second path, i.e. diversify their incomes through non-agricultural activities. Their investment activity both in agricultural and non-agricultural activity is analysed. The investments may be considered one of the main determinants of development, both for agricultural holdings and non-agricultural entities, thus investment decisions are among the most important decisions made by these entities. The prospective competitiveness of agricultural holdings and non-agricultural entities, and thus the ability of income generation of farmers and their families depend on the accuracy of these decisions.

\section{Research objective and methodology}

The main aim of the study is to analyse material investments carried out between 2004 and 2015 by small agricultural holdings owners conducting at the same time non-agricultural activities and their plans regarding the future of their activities. The empirical material consisted of the results of own survey-based research conducted in 2015 on the development of non-agricultural activities of the owners of small agricultural holdings. The research included farmers from the Małopolskie Province owning agricultural holdings of $1-5$ ha of arable land. The region was selected on purpose, as the Małopolskie Province has one of the most fragmented agricultural structures in Poland.

Due to the research subject, i.e. the analysis of investment activity of farmers conducting additional non-agricultural activity, a list of farmers owning holdings of 1-5 ha of arable land, who between 2004 and 2015 obtained investment aid from programmes carried out within the Common Agricultural Policy such as the Rural Development Plan for 2004-2016, Sectoral Operational Programme "Restructuring and Modernisation of the Food Sector and Rural Development 2004-2006", and/or 
Rural Development Programme for 2007-2013 at least once was the assumed sampling frame. The research was conducted in several stages. During the first stage, 301 randomly selected farmers were included in the research. Among them, 80 farmers conducting non-agricultural economic activity were identified and qualified to the subsequent stages. The respondents came from 41 municipalities in 14 district of the Małopolskie Province.

\section{Research results}

Farmers owning agricultural holdings with 1-5 ha of arable land conducting nonagricultural business activities at the same time participated in the study. In Table 1, selected traits of the respondents and their agricultural holdings are presented. Men prevailed in the studied population. The largest group were persons between 30 and 40 years old (40\% of all respondents) and the second largest group were persons between 40 and 50 years old (37.5\%). Study participants were characterized by a relatively high level of education, as $73.7 \%$ have completed secondary or tertiary education, and only $26.3 \%$ have completed basic vocational education. Simultaneously, over half of the respondents had an agricultural education.

Farmers with diverse areas of arable land participated in the study. Almost 59\% had over 4 ha of arable land, one fifth between 3 and 4 ha, 11\% between 2 and 3 ha, and $10 \%$ up to 2 ha. All respondents conducted plant production. The dominant crops, i.e. crops with the biggest economic significance in a given agricultural holding included: cereals, vegetables cultivated outdoors and under covers were indicated the most often. At the same time, only $11.0 \%$ of the studied holdings conducted animal production, usually pigs.

In addition to agricultural activity, the respondents conducted non-agricultural activity (Table 2). It was mostly registered activity $(91.2 \%)$. Only $8.8 \%$ respondents conducted rural tourism activity, which is a non-registered agricultural activity.

The majority of respondents provided services $(67.5 \%)$, mostly concerning construction, services provided to agriculture, or rural tourism. Trading activity, mostly wholesale of fruits and vegetables, and production (food processing, metal products manufacturing, furniture production) was much less popular. The time of conducting such activity varied, but for $81.2 \%$ respondents it was over 2 years. Over three quarters of the respondents started their non-agricultural activities in 2004 and in the subsequent years. $52.5 \%$ did not employ anyone for purposes of their nonagricultural activity, which shows that it usually took on the form of self-employment. Usually, it was local or regional. Only $16.2 \%$ declared the whole country as their market. 
Table 1. Selected traits of the respondents and their agricultural holdings

\begin{tabular}{|c|c|c|c|}
\hline & Selected traits & No. of answers & $\%$ of answers \\
\hline \multirow{2}{*}{ Gender } & woman & 13 & 16.2 \\
\hline & $\operatorname{man}$ & 67 & 83.8 \\
\hline \multirow{3}{*}{$\begin{array}{l}\text { Age of the } \\
\text { respondent }\end{array}$} & over 30 to 40 years & 32 & 40.0 \\
\hline & over 40 to 50 years & 30 & 37.5 \\
\hline & over 50 years & 18 & 22.5 \\
\hline \multirow{6}{*}{$\begin{array}{l}\text { Education of } \\
\text { the } \\
\text { respondent }\end{array}$} & basic vocational & 21 & 26.3 \\
\hline & secondary vocational & 34 & 42.5 \\
\hline & secondary general & 3 & 3.7 \\
\hline & tertiary & 22 & 27.5 \\
\hline & has agricultural training & 44 & 55.0 \\
\hline & no agricultural training & 36 & 45.0 \\
\hline \multirow{4}{*}{$\begin{array}{l}\text { Area of } \\
\text { arable land in } \\
\text { the holding }\end{array}$} & up to 2 ha & 8 & 10.0 \\
\hline & over 2 to 3 ha & 9 & 11.2 \\
\hline & over 3 to 4 ha & 16 & 20.0 \\
\hline & over 4 ha & 47 & 58.8 \\
\hline \multirow{6}{*}{$\begin{array}{l}\text { Dominant } \\
\text { plant } \\
\text { production }\end{array}$} & cereal & 32 & 40.0 \\
\hline & potatoes & 8 & 10.0 \\
\hline & vegetables & 32 & 40.0 \\
\hline & cultivation under covers & 27 & 33.8 \\
\hline & fruit trees and shrubs & 6 & 7.5 \\
\hline & other crops & 13 & 16.3 \\
\hline \multirow{4}{*}{$\begin{array}{c}\text { Animal } \\
\text { production } \\
\text { conducted }\end{array}$} & cattle for slaughter & 2 & 2.5 \\
\hline & dairy cattle & 3 & 3.8 \\
\hline & pigs & 4 & 5.0 \\
\hline & horses & 1 & 1.3 \\
\hline
\end{tabular}

Table 2. Characteristics of non-agricultural activities of the respondents

\begin{tabular}{clcc}
\hline \multicolumn{2}{c}{ Selected characteristics } & No. of answers & \% of answers \\
\hline Length of the period of & less than 2 years & 15 & 18.8 \\
conducting non- & 2 to 5 years & 29 & 36.2 \\
agricultural activity & over 5 years & 36 & 45.0 \\
& no employees & 42 & 52.5 \\
Number of employees & 1 employee & 24 & 30.0 \\
& 2 or more employees & 14 & 17.5 \\
Market of non- & local & 34 & 42.5 \\
agricultural activity & regional & 33 & 41.3 \\
& national & 13 & 16.2 \\
\hline
\end{tabular}


During the research, an attempt to identify all investment measures used by the farmers-entrepreneurs between 2004 and 2015 for the development of their agricultural or non-agricultural activity and the value of investment expenses incurred and subsidies granted was made. The relevant data is presented in Table 3.

Table 3. Basic characteristics of support granted to the respondents between 2004 and 2015 within the studied programmes

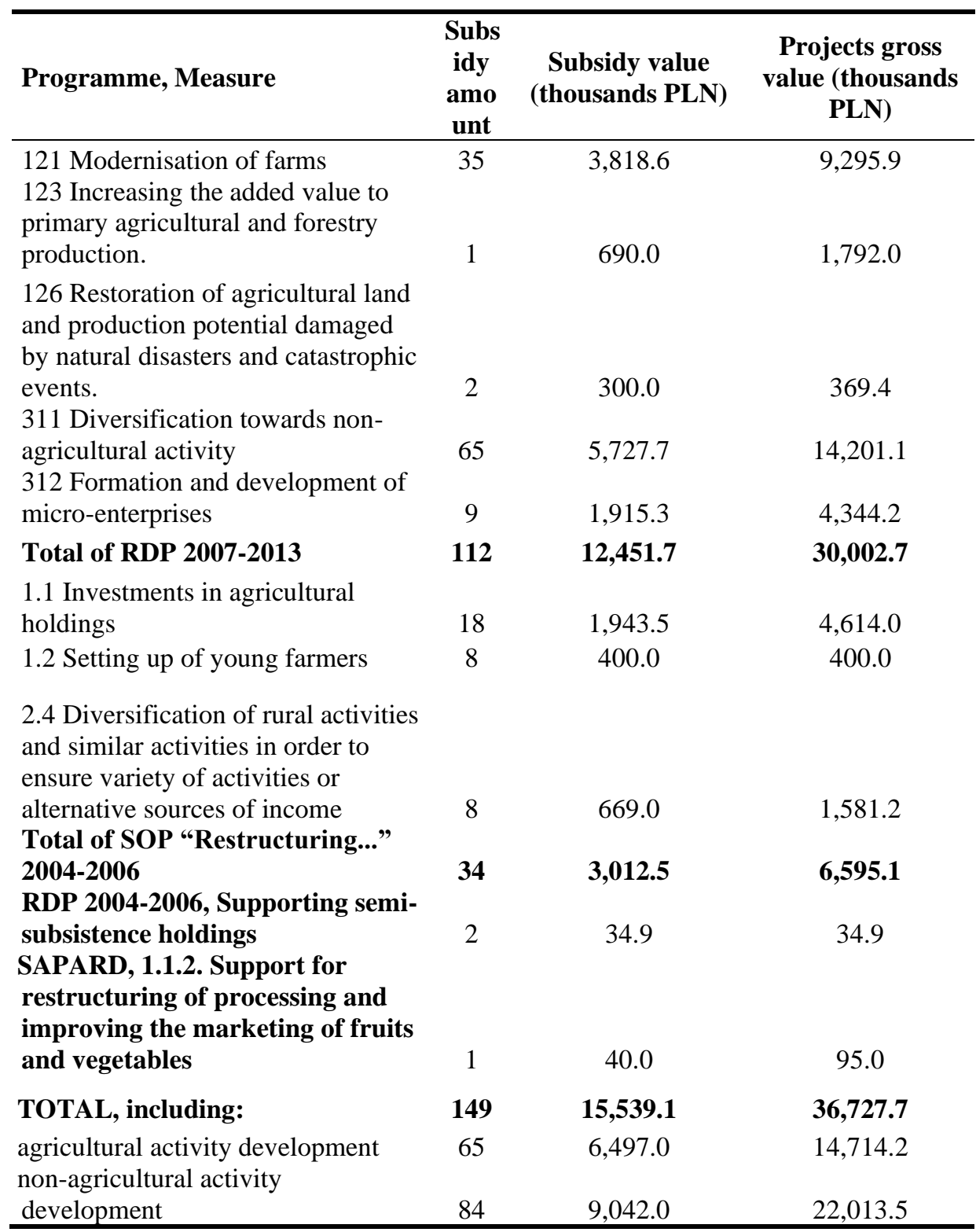


80 studied beneficiaries obtained 149 investment subsidies of PLN 15.5 million in total, carrying out project the total value of which was PLN 36.7 million. Most of the subsidies were granted within the Rural Development Programme (RDP) for 20072013, which constituted $80.1 \%$ of the overall amount of support. Additionally, the beneficiaries obtained subsidies from the Sectoral Operational Programme "Restructuring and Modernisation of the Food Sector and Rural Development 20042006 ", the value of which was $19.4 \%$ of the overall amount of support. There were also two beneficiaries of the Rural Development Plan for 2004-2016 and one of the Sapard pre-accession programme.

The analysis of the structure of the subsidies showed that $65 \%$ subsidies for agricultural activities development for a total amount of PLN 6.5 million for carrying out projects worth PLN 14.7 million in total, and 84 subsidies for non-agricultural activities development for a total amount of PLN 9.0 million for the purposes of projects worth PLN 22.0 million in total were obtained in the studied period. This means that over a half of the subsidies allocated to non-agricultural activities development, which constituted $58.2 \%$ of all the support in value terms. It is worth noting that investment outlays on non-agricultural activity constituted $59.9 \%$ of total outlays, which can lead to a conclusion that they were usually more capital-intensive than investments made in agricultural holdings. The average value of a funded investment project was PLN 262.1 thousand for non-agricultural activity and PLN 226.4 thousand for agricultural activity. The largest subsidies of investment outlays were granted between 2007 and 2013 from the Rural Development Programme, whereby investments in agricultural holdings were co-financed mostly from measure 121 - Modernisation of farms, whereas non-agricultural activity support came mostly from the resources of measure 311 - Diversification towards non-agricultural activity.

The analysis of the structures of investment outlays on the development of agricultural and non-agricultural activities showed that they were similar (table 4). Among the expenses on agricultural activity, expenses on the purchase of machines, instruments, tools, and equipment prevailed (65.8\% of overall subsidy value). Funds were also allocated for the extension or modernisation of holdings and increase in arable land. Farmers investing in non-agricultural activity development also spent their resources mostly on the purchase of machines, instruments, tools, and equipment. Another direction of spending were the extension or modernisation of holdings, construction of new facilities for the purpose of non-agricultural activity, and the extension or modernisation of residential buildings for rural tourism purposes and their equipment.

All respondents benefited from the subsidies within the studied programmes. $27.5 \%$ benefited from a donation granted within 1 measure and $57.5 \%$ obtained subsidies from two different measures. $15.0 \%$ obtained support three times. Therefore, one can conclude that the studied group of farmers was very active in terms of acquiring EU funds for investments. 
Table 4. Value and structure of subsidies classified by categories of investment outlays incurred

\begin{tabular}{|c|c|c|c|c|}
\hline \multirow[b]{2}{*}{ Investment expense category } & \multicolumn{2}{|c|}{$\begin{array}{l}\text { Investments in } \\
\text { agricultural activity }\end{array}$} & \multicolumn{2}{|c|}{$\begin{array}{l}\text { Investments in } \\
\text { non-agricultural } \\
\text { activity }\end{array}$} \\
\hline & $\begin{array}{l}\text { Subsidy } \\
\text { value } \\
\text { (thousands } \\
\text { PLN) }\end{array}$ & $\begin{array}{l}\text { Share in } \\
\text { the total } \\
\text { subsidy } \\
\text { amount } \\
{[\%]}\end{array}$ & $\begin{array}{l}\text { Subsidy } \\
\text { value } \\
\text { (thousand } \\
\text { s PLN) }\end{array}$ & $\begin{array}{c}\text { Share in } \\
\text { the total } \\
\text { subsidy } \\
\text { amount } \\
{[\%]}\end{array}$ \\
\hline $\begin{array}{l}\text { purchase of machines, } \\
\text { instruments, tools, and } \\
\text { equipment }\end{array}$ & $4,275.1$ & 65.8 & $5,829.6$ & 64.5 \\
\hline increase of arable land & 620.0 & 9.5 & - & - \\
\hline $\begin{array}{l}\text { extension or modernisation of } \\
\text { holdings } \\
\text { extension or modernisation of } \\
\text { buildings for rural tourism } \\
\text { purposes and their equipment }\end{array}$ & $1,300.0$ & 20.0 & $1,700.0$ & 18.8 \\
\hline $\begin{array}{l}\text { construction of a new building } \\
\text { purchase of a mean of } \\
\text { transportation }\end{array}$ & - & - & 888.7 & 9.8 \\
\hline $\begin{array}{l}\text { agricultural holding land } \\
\text { development }\end{array}$ & 292.0 & 4.5 & - & - \\
\hline Purchase of animals & 10.0 & 0.2 & - & - \\
\hline Total investment expenses & $6,497.0$ & 100.0 & $9,042.0$ & 100.0 \\
\hline
\end{tabular}

The development of agricultural activity by farmers owning small agricultural holdings may pose some risk of marginalising the importance of agricultural activity. Launching alternative types of activity may lead to the cessation of investments in agricultural activity and relocation of resources to activities providing higher revenue, the consequence of which may be the slow, several-stage liquidation of agricultural holding. However, research results show that the owners of small agricultural holdings usually tried to invest in both activities at the same time. 58.7\% respondents made parallel investments in both types of activity. A little over one third of the studied group $(36.3 \%)$ benefited from subsidies only for the development of agricultural activity and only $5.0 \%$ invested only in agricultural activity.

The analysis of directions of investments in different types of non-agricultural activities provided interesting conclusions (Table 5). Thus, it should be stated that conducting non-agricultural activities in a sector not related with existing agricultural activity and not based on any agricultural holding resources clearly encouraged farmers to invest only in non-agricultural activity. In this case, only $13.0 \%$ of farmers conducting non-agricultural activity invested also or only in their agricultural activity. 
Table 5. Percentage of farmers investing in agricultural and non-agricultural depending on type of non-agricultural activity

\begin{tabular}{|c|c|c|c|c|c|}
\hline $\begin{array}{l}\text { Type of non- } \\
\text { agricultural activity }\end{array}$ & $\begin{array}{l}\text { Examples of } \\
\text { activities of the } \\
\text { respondents }\end{array}$ & $\begin{array}{l}\text { agricult } \\
\text { ural } \\
\text { activity }\end{array}$ & $\begin{array}{l}\text { of answe dir } \\
\text { onsw- } \\
\text { non- } \\
\text { agricult } \\
\text { ural } \\
\text { activity }\end{array}$ & $\begin{array}{l}\text { ction } \\
\text { rs] } \\
\text { agricult } \\
\text { ural and } \\
\text { non- } \\
\text { agricult } \\
\text { ural } \\
\text { activity }\end{array}$ & Total \\
\hline $\begin{array}{l}\text { Activity not related } \\
\text { with existing } \\
\text { agricultural activity } \\
\text { conducted outside } \\
\text { own agricultural } \\
\text { holding or in own } \\
\text { agricultural holding } \\
\text { without using its } \\
\text { resources }\end{array}$ & $\begin{array}{l}\text { construction } \\
\text { services, furniture } \\
\text { production, technical } \\
\text { counselling, food } \\
\text { production not based } \\
\text { on processing own } \\
\text { agricultural holding } \\
\text { products }\end{array}$ & 4.3 & 87.0 & 8.7 & 100.0 \\
\hline $\begin{array}{l}\text { Activity not related } \\
\text { with existing } \\
\text { agricultural activity, } \\
\text { but based on } \\
\text { agricultural holding } \\
\text { resources }\end{array}$ & $\begin{array}{l}\text { accommodation and } \\
\text { catering services, } \\
\text { including rural } \\
\text { tourism, diverse } \\
\text { types of service } \\
\text { provision or } \\
\text { production }\end{array}$ & 0.0 & 46.7 & 53.3 & 100.0 \\
\hline $\begin{array}{l}\text { Related activity, } \\
\text { connected with } \\
\text { existing agricultural } \\
\text { activity, based on } \\
\text { agricultural holding } \\
\text { resources }\end{array}$ & $\begin{array}{l}\text { services supporting } \\
\text { agriculture, rental } \\
\text { and leasing of } \\
\text { agricultural } \\
\text { machines and } \\
\text { instruments }\end{array}$ & 8.7 & 8.7 & 82.6 & 100.0 \\
\hline $\begin{array}{l}\text { Activities including } \\
\text { activities preceding } \\
\text { or following the } \\
\text { existing process of } \\
\text { agricultural } \\
\text { production }\end{array}$ & $\begin{array}{l}\text { wholesale of own } \\
\text { agricultural products, } \\
\text { processing of own } \\
\text { agricultural products }\end{array}$ & 5.3 & 0.0 & 94.7 & 100.0 \\
\hline
\end{tabular}

Conducting an activity unrelated with the existing agricultural activity, but using the resources of agricultural holding, such as rural tourism activity, also resulted in investing mostly in non-agricultural activity, but encouraged farmers to simultaneously invest in agricultural activity to a greater extent. The farmers were encouraged to invest in agricultural holdings and non-agricultural activity in parallel usually by the activities that were related to agriculture, connected with the existing activity, or included activities preceding or following the existing process of 
agricultural production. The percentage of farmers investing in both types of activities was $82.6 \%$ and $94.7 \%$, respectively.

During the research, farmers' plans regarding their future agricultural and nonagricultural activities were also analysed. The answers show that all farmers who invested both in agricultural and non-agricultural activities between 2004 and 2015 want to keep developing these activities simultaneously. Among the farmers who invested only in the development of non-agricultural activities in the studied period, $65.5 \%$ plan to stop conducting agricultural activity and focus only on non-agricultural activity. The remaining $34.5 \%$ want to keep developing these activities simultaneously. The majority of persons who invested only in their agricultural holdings plan to keep combining the two types of activity and only one person wants to withdraw from agriculture. In general, a quarter of the respondents wants to stop conducting agricultural activity in favour of a non-agricultural activity, whereas three quarters of them plan to conduct both types of activity simultaneously, diversifying their sources of income.

\section{Conclusions}

Analysing the directions of devoting resources to investments carried out between 2004 and 2015 by small agricultural holding owners conducting non-agricultural business activity at the same time, it was found that these persons usually invested both in agricultural and non-agricultural activities A smaller group of respondents invested only in non-agricultural activity, whereas only a few persons invested only in their agricultural activity. However, it was found that larger investments were made in non-agricultural activities. In this area, more investments were carried out in terms of both number and value. Non-agricultural investments were usually more capitalintensive than investments in agriculture. The material structures of the incurred outlays were similar: thanks to investments, the respondents expanded their fixed assets resources, mostly machines, instruments, tools, and equipment. Outlays on new or existing farm buildings or other types of material investments were incurred much less often.

The directions of devoting resources to investments were determined by the nature of non-agricultural activity. It can be stated that close relation of non-agricultural activity with the holding encouraged investments in both types of activity more often, whereas conducting non-agricultural activity not related with agriculture and not based on agricultural holding resources was more likely to encourage farmers to invest only in non-agricultural activity.

As mentioned before, the diversification of sources of income thanks to nonagricultural activity may lead to a gradual reduction of agricultural activity, and in extreme cases, to the total liquidation of an agricultural holding. Research results show that obtaining a source of income thanks to investing in non-agricultural activity is a factor encouraging every fourth farmer to withdraw from agricultural activity in the future. This concerns mostly those who carried out investments in non-agricultural activity, so mostly persons conducting non-agricultural activity not related with 
agriculture or agricultural holding. They will undergo a process of gradual reduction of agricultural activity, which may lead to withdrawing from it, ultimately leading to the total liquidation of a small agricultural holding.

However, three quarters of respondents do not plan to abandon their agricultural activities. They choose the strategy of development of non-agricultural business activity considering it an additional source of income. Therefore, it can be stated that for them, the non-agricultural business activity is a factor supporting the survival or even the development of an agricultural holding. Undertaking activities related with agriculture or agricultural holdings and using their resources contributes to the implementation of this strategy.

In light of research result, it can be concluded that the two areas of activity conducted by small holdings owners, i.e. agricultural and non-agricultural activity, are interconnected and material investments are a factor stimulating the implementation of two different strategies of restructuring small agricultural holdings. In the case of economically weak holdings, they allow farmers to withdraw from agricultural activity thanks to the development of non-agricultural activity. On the other hand, the operation and development of an agricultural holding usually depend on the possibility of support of agricultural activity through non-agricultural activity. In this case, they become factors allowing for the survival or even development of a small agricultural holding, assuring a non-agricultural source of income thanks to opportunities or resources acquired through non-agricultural activity.

Acknowledgements. Publication financed by funds granted to the Management Faculty of Cracow University of Economics under the scheme for subsidising university research potential.

\section{References}

1. Eurostat: Small and large farms in the EU - statistics from the farm structure survey, http://ec.europa.eu/eurostat/statistics-explained/index.php/Small_and_large_farms_in _the _EU___statistics_from _the_farm_structure_survey, last accessed 2017/10/15.

2. Forgacs, C.: Development of Small Farms in EU 10 (CEECS) Between 2005-2010. In: Raupeliené A. (eds.) 7th International Scientific Conference Rural Development 2015 Towards the Transfer of Knowledge, Innovations and Social Progress. Aleksandras Stulginskis University, Lithuania (2015).

3. Grochowska, R.: Polish experience from the transformation period and the EU membership, future, challenges and strategies for small farm holders, http://www.fao.org/fileadmin/user_upload /reu/ europe/documents /Events 2015 /fcss/pol_en.pdf, last accessed 2017/10/18.

4. Musiał, W., Drygas, M.: Dylematy procesu delimitacji drobnych gospodarstw rolnych. Wieś i Rolnictwo 159(2), 55-74 (2013).

5. Ostromęcki, A., Zając, D., Mantaj, A.: The importance of non-agricultural economic activity of farmers in the modernization process of farms. Acta Sci. Pol., Oeconomia 14(4), 83-92 (2015). 
6. Veveris, A., Sapolaite, V.: Accessibility of Rural Development Programme Support for Small Rural Farms in Latvia and Lithuania. In: Auzina, A. (eds.) Economic Science for Rural Development 2017, vol. 44, pp. 345-352, Latvia University of Agriculture, Jelgava (2017).

7. Wojewodzic, T.: Dywestycje produkcyjne i zasobowe $\mathrm{w}$ gospodarstwach rolniczych prowadzonych przez przedsiębiorców. Roczniki Naukowe Stowarzyszenia Ekonomistów Rolnictwa i Agrobiznesu 13(2), 532-535 (2011).

8. Wojewodzic, T.: Dywestycje w gospodarstwach rolnych - istota, definicje, podział. Wieś i Rolnictwo 2, 96-108 (2010).

9. Żmija, D.: Wpływ wspólnej polityki rolnej Unii Europejskiej na funkcjonowanie małych gospodarstw rolnych w Polsce. Difin, Warsaw (2016).

10. Żmija, D., Żmija, K.: Sustainable Development in the Functioning of Small Agricultural Holdings. In: Jedlička P., Marešová P., Soukal I. (eds.) Hradec Economic Days: Doubleblind Peer Reviewed Proceedings of the International Scientific Conference Hradec Economic Days 2017, pp. 973-979. The University of Hradec Králové, Hradec Králové (2017). 